УДК 37.018

DOI https://doi.org/10.32782/apv/2021.6.7

\title{
Ганна ЗАХАРОВА
}

кандидат педагогічних наук, доиент,

дочент кафедри педагогіки, іноземної філологї та перекладу, Харківський національний економічний університет імені Семена Кузнеия, пр. Науки, 9А, м. Харків, Україна, 61166

ORCID: 0000-0002-3885-5130

\section{Ярослава ЛЮТВІЕВА}

старший викладач кафедри педагогіки, іноземної філологї та перекладу, Харківський наиіональний економічний університет імені Семена Кузнеия, пр. Науки, 9А, м. Харків, Украӥна, 61166

ORCID: 0000-0002-5874-5692

Бібліографічний опис статті: Захарова, Г., Лютвієва, Я. (2021). Важливість засобів масової комунікації у відображенні педагогічного досвіду (друга половина ХХ століття). Acta Paedagogica Volynienses, 6, 40-45, doi: https://doi.org/10.32782/apv/2021.6.7

\section{ВАЖЛИВІСТЬ ЗАСОБІВ МАСОВОЇ КОМУНІКАЦІЇ У ВІДОБРАЖЕННІ ПЕДАГОГІЧНОГО ДОСВІДУ (ДРУГА ПОЛОВИНА ХХ СТОЛІТТЯ)}

У статті здійснено аналіз досліджень різних науковиів із теми розповсюдження педагогічного досвіду; наведено основні визначення термінів «комунікація», «засоби масової комунікації»; встановлено характерні риси для всіх груп засобів масової комунікації, рівні, на яких реалізується стан масової комунікації. Визначено, щзо функиії засобів масової комунікації зводяться до п'яти «елементарних», зроблено аналіз кожної них. У статті визначено, щзо ЗМК притаманні такі риси, як соціальна природа, форми та технологї̈ впливу на свідомість людей. Зміст діяльності иьвого інституту становить інформування широких верств населення про моральні норми та правила поведінки, науково-педагогічні здобутки; розвиток духовної, естетичної, фізичної, трудової, правової культури аудиторії; поширення передового педагогічного досвіду тощо. Доведено, щуо засоби масової комунікацї стали важливим чинником формування особистості, ї̈ світогляду та моделі поведінки, вони мають значні можливості здійснювати культурний, виховний, ідеологічний, політичний вплив на людей, формувати свідомість і навіть змінювати спосіб мислення громадян.

Масова комунікачія як сочіально зумовлене явище через систему наявних каналів зв'язку здійснює вплив на аудиторію, доводить різноманітну інформацію до широкої громадськості та суспільства. До засобів масової комунікації як спеціальних каналів, завдяки яким відбувається поширення інформаційних повідомлень для масової аудиторії, належать періодичні видання, кіно, театр, радіо і телебачення, технічні засоби комунікації, інтернет-сайти тощу. Серед численних функцій ЗМК, таких як інформаційна, аналітична, морально-виховна, иіннісно-орієнтаційна, комунікативна, сочіальна, гедоністична, чільне місце займає пізнавально-просвітницька. Передаючи різноманітну культуру, історичну, наукову, освітню інформацію, мас-медіа сприяють поповненню фонду знань своїх читачів, слухачів і глядачів.

Розповсюдження передового педагогічного досвіду засобами масової комунікації реалізується в інформаційному, комунікаційному, навчальному та експертному напрямі. У статті на основі аналізу значного масиву літератури з ясовано роль і значення засобів масової комунікачії у відображенні теорії педагогічного досвіду і практики його вивчення, узагальнення і розповсюдження.

Ключові слова: засоби масової комунікачії, передовий педагогічний досвід, освітньо-виховний прочес, учитель, виховання, школа, дослідження.

\section{Hanna ZAKHAROVA}

Candidate of Pedagogical Sciences, Associate Professor, Associate Professor at the Department of Pedagogy, Foreign Philology and Translation, Simon Kuznets Kharkiv National University of Economics, Nauky Ave., $9 A$, Kharkiv, Ukraine

ORCID: 0000-0002-3885-5130 
Yaroslava LYUTVIYEVA

Senior Lecturer at the Department of Pedagogy, Foreign Philology and Translation, Simon Kuznets Kharkiv National University of Economics, Nauky Ave., 9A, Kharkiv, Ukraine

ORCID: 0000-0002-5874-5692

To cite this article: Zakharova, G., Lyutviyeva, Ya. (2021). Vazhlyvist' zasobiv masovoyi komunikatsiyi $\mathrm{u}$ vidobrazhenni pedahohichnoho dosvidu (druha polovyna XX stolittya). [The importance of mass media in reflecting pedagogical experience (second half of xx century)]. Acta Paedagogica Volynienses, 6, 40-45, doi: https://doi.org/10.32782/apv/2021.6.7

\section{THE IMPORTANCE OF MASS MEDIA IN REFLECTING PEDAGOGICAL EXPERIENCE (SECOND HALF OF XX CENTURY)}

The article presents an analysis of research by various scholars on the dissemination of pedagogical experience, provides basic definitions of the terms "communication", "mass media", establishes the characteristics of all groups of mass media, the levels at which the state of mass communication is realized. that the functions of the media are reduced to five "elementary", an analysis of each of them. The paper analyzes that the WMC has the following features: social nature, forms and technologies of influence on human consciousness. The content of the activities of this institute is to inform the general population about moral norms and rules of conduct, scientific and pedagogical achievements; development of spiritual, aesthetic, physical, labor, legal culture of the audience; dissemination of advanced pedagogical experience, etc. It is proved that the media have become an important factor in shaping the individual, his worldview and behavior, they have significant opportunities to exercise cultural, educational, ideological, political influence on people, shape consciousness and even change the way of thinking of citizens. Mass communication as a socially conditioned phenomenon through the system of existing communication channels has an impact on the audience, brings a variety of information to the general public and society. The mass media include special periodicals, cinema, theater, radio and television, technical means of communication, Internet sites, etc. as special channels through which information messages are disseminated to the mass audience. Among the many functions of mass communication (informational, analytical, moraleducational, value-oriented, communicative, social, hedonistic) cognitive-educational occupies a prominent place. By transmitting diverse culture, historical, scientific, and educational information, the mass media contribute to replenishing the knowledge base of their readers, listeners, and viewers. Dissemination of advanced pedagogical experience through the media is implemented in the information, communication, training and expertise. The article, based on the analysis of a large body of literature, clarifies the role and importance of the media in reflecting the theory of pedagogical experience and the practice of its study, generalization and dissemination.

Key words: mass media, advanced pedagogical experience, educational process, teacher, upbringing, school, research.

Актуальність проблеми. Важливим резервом підвищення ефективності діяльності загальноосвітньої школи є широке впровадження у практику передового педагогічного досвіду, використання кращих здобутків як учителів-практиків, так і науковців у процесі навчання i виховання підростаючого покоління. У процесі відображення передового досвіду важливу роль відіграють засоби масової комунікації.

Аналіз останніх досліджень. Передовий освітньо-виховний досвід як актуальна педагогічна проблема другої половини XX ст. досліджувався в різних аспектах. Так, методологічні основи взаємозв'язку науки і практики наведено у працях П. Атутова, В. Загвязинського, В. Журавльова, В. Краєвського, С. Моносзона, М. Скаткіна; визначення категоріального апарату, розкриття суті ППД, його ознак, видів, функцій, умов реалізації здійснено у роботах
Л. Аристової, Ю. Бабанського, А. Бойко, В. Бондаря, I. Кривоноса, М. Таланчука, Ф. Тереулова, Т. Шамової. До передового досвіду як джерела й основи вдосконалення змісту освіти зверталися В. Свдокимов, І. Журавльов, В. Ледньов, В. Лозова; умови, форми і методи вивчення і використання передового педагогічного досвіду ставали предметом досліджень Б. Бітінаса, О. Куракіна, Н. Шилової та інших. Питання диференціації ППД (політехнічний, трудовий досвід, досвід із професійної орієнтації) розглядали П. Атутов, К. Ахіяров, С. Матушкін, В. Поляков, О. Сазонов, М. Томін, П. Чернецов та інші.

Виклад основного матеріалу дослідження. Сучасний етап розвитку суспільних відносин передбачає використання поняття «комунікація», що $є$ базовою умовою існування людської спільноти, характеристикою інформаційних процесів у соціумі. Комунікація як формальна категорія 
знань розглядається досить широко. Не набула сталості й дефініція терміна «комунікація», свідченням чого є занадто велика кількість визначень: понад 120 за даними Ф. Данса і К. Ларсона станом на 1972 р. і понад 240 за даними Д. Андерсена станом на 1996 р. (Онуфрієнко, 2015).

Отже, комунікація - це зумовлений ситуацією i соціально-психологічними особливостями комунікаторів процес встановлення і підтримання контактів між членами певної соціальної групи чи суспільства загалом на основі духовного, професійного або іншого єднання учасників комунікації, який відбувається у вигляді взаємопов'язаних інтелектуально-мисленнєвих та емоційно-вольових актів, опосередкованих мовою і дискретних у часі та просторі, що пов'язані із процесами збору фактів, їх зберігання, аналізу, переробки, оформлення, висловлення, поширення, сприймання і розуміння, відбуваються 3 використанням або без нього різних знакових систем, зображень, звуків (письмо, жести, міміка тощо), засобів комунікації (газети, журнали, аудіовізуальні програми тощо), засобів зв'язку (телефон, телеграф, транспорт тощо), результатом яких $\epsilon$ конкретна інтелектуально-мисленнєва й емоційно-вольова поведінка співбесідника, конкретні результати його діяльності, прийняті ним рішення, що задовольняють членів певної соціальної групи або суспільства загалом.

Вивчення наукової літератури із проблеми дослідження (Баришполець, 2014; Городяненко, 2003; Квіт, 2008) засвідчило, що комунікація може бути вербальною (передача інформації за допомогою усних чи друкованих слів), візуальною (за допомогою образного ряду), орієнтованою на сприйняття за допомогою слуху (музична), невербальною (коли одержувач інформації інтерпретує міміку, жести, символи тощо), комбінованою.

Інформація - це зміст логічно побудованої думки, який сприймається за допомогою почутого або побаченого слова, вона може бути використана людьми в їхній діяльності. Комунікація пов'язана із передачею інформації, але не обмежується лише цим. Тому часто розмежовують поняття масової комунікації та масової інформації. Масова інформація - стереотипізована інформація, яка оперативно та регулярно поширюється на велику, географічно розпорошену аудиторію (Городяненко., 2003).
Інформація і комунікація є двома рівнями процесу спілкування. Перший - пізнавальний (когнітивний) - пов'язаний із поширенням соціально важливих відомостей серед широкої аудиторії. На цьому рівні інформація створює умови для пізнавальної діяльності соціальних суб'єктів, є пізнавальним ресурсом під час формування уявлень, ціннісних орієнтирів, стереотипів поведінки тощо. На другому рівні процесу спілкування одержана соціальним суб'єктом інформація поєднується із системою існуючих норм і цінностей, регулює контакти 3 навколишнім середовищем, передусім соціальним. За цих умов процес комунікації має безпосередній стосунок до соціальної дії.

Зазначене свідчить, що масова комунікація розгалуженіший процес, який суттєво впливає на функціонування соціуму. 3 масовою інформацією іiі ріднить те, що обидві вони реалізуються лише засобами масової інформації (3МI) і не можуть існувати поза ними. Комунікація за своєю природою є конституюючим фактором суспільного розвитку. На ранніх етапах суспільного розвитку комунікація мала виключно операціональний рефлекторно-поведінковий характер і залежала від вітальних, тобто життєвозабезпечувальних, потреб людей. Із суспільним розвитком і перетворенням комунікації на систему усвідомлених, цілеспрямованих дій, скерованих на процес свідомого встановлення і підтримання контактів між членами суспільства, спілкування стало набирати характеру творчого процесу, коли реакція комуніката прогнозувалася мовцем, формувалася спеціально.

Вивчення наукової літератури із проблеми дослідження (Баришполець, 2014; Городяненко, 2003; Квіт, 2008) дало змогу встановити, що, виходячи 3 етимології поняття «масова комунікація» (масове спілкування, mass communication), iii розуміють як організоване спілкування, що є видом суспільно-культурної діяльності, яка відбувається у вигляді взаємопов'язаних інтелектуально-розумових та емоційно-вольових дій, спрямованих на духовне, професійне чи інше єднання маси людей (мас). Основним у цьому визначенні $\epsilon$ поняття комунікації як організованого спілкування або діяльності, тобто такої активності людей, яка має свої мотиви, свою структуру, яка складається із конкретних дій, підпорядкованих загальній меті. 
У процесі дослідження встановлено, що стан масової комунікації реалізується на двох рівнях: когнітивному й інтерактивному (Макеєв, 2003). Перший пов'язаний із процесами поширення соціально значущої інформації серед аудиторій, які охоплюють більшу частину населення. На когнітивному рівні слово «інформація» інтерпретується найчастіше як «ознайомлення». Соціальні за змістом відомості, які транслюються каналами макрокомунікації (популярні знання про світ, ціннісно забарвлені зразки поведінки, норми взаємодії суб'єктів різного соціального статусу, культурні стереотипи), створюють інформаційну основу для когнітивної (пізнавальної) діяльності соціальних суб'єктів різного рангу. Занурюючись у масову комунікацію, вони здатні використовувати отриману інформацію як пізнавальний ресурс у процесі формування своїх уявлень, думок, ціннісних орієнтацій.

На інтерактивному рівні інформація становить ресурс соціальної дії у різних формах. Отримавши інформацію, індивід чи група співвідносять себе із конкретним культурним колом, етнічною спільнотою, політичним рухом, тобто здійснюють соціальну і ціннісну ідентифікацію. За допомогою каналів масової комунікації вони символічно взаємодіють і конкурують за пріоритет створених ними образів, беруть участь у формуванні громадської думки і настроїв.

Узагальнення цих тверджень свідчить, що масова комунікація $\epsilon$ соціально зумовленим явищем, основною функцією якого $є$ вплив на аудиторію через систему наявних сучасних каналів зв'язку, за допомогою яких доводиться різноманітна інформація до широкої громадськості, суспільства. Це - відносно самостійна система, яка характеризується розмаїттям компонентів як матеріального (засоби, матеріали, установки), так і соціального (професійні кадри) й організаційного (зміст, методи, форми реалізації діяльності) змісту. Неодмінною умовою здійснення масової комунікації $є$ наявність технічних засобів, що забезпечують регулярність і тиражованість масової комунікації. Під засобами масової комунікації розуміють спеціальні канали, завдяки яким відбувається поширення інформаційних повідомлень для масової аудиторії. Серед засобів, що забезпечують комунікацію, прийнято розрізняти засоби масової інформації, засоби масового впливу і технічні засоби. До ЗМІ належать друковані періодичні видання (преса), радіо і телебачення, їхня історія різна за тривалістю, розрізняються i їхне призначення, i канали впливу на аудиторію. До засобів масового впливу належать кіно, театр, цирк, усі видовищні покази і художня література. Засоби масового впливу не відрізняються регулярністю звертання до масової аудиторії. Технічні засоби комунікації (телефон, телетайп, засоби кабельного і супутникового зв'язку, Інтернет тощо) не мають масового охоплення аудиторії, і передана інформація може мати особистий характер, не пов'язаний із соціально значущими сторонами життя.

Вивчення наукової літератури із проблеми дослідження (Городяненко, 2003; Квіт 2008; Почепцов, 1999) дало змогу встановити, що, попри специфічні властивості кожної групи ЗМК, характерними для всіх них є такі риси, як:

- масовість, періодичність діяльності та доступність ЗМК (у технічному, фінансовому, соціально-економічному, культурному плані тощо) у розповсюдженні інформації ЗМК забезпечують регулярність і тиражування інформації;

- здійснення та розвиток зв'язку між різними соціальними групами; масова аудиторія характеризується неоднорідністю (за територіальною ознакою) й анонімністю. У соціології індивіди, що утворюють цю аудиторію, розглядаються як особистості, шо включені в мережу реальних суспільних відносин і зв'язків. Саме за допомогою масової комунікації ці особистості можуть установити і підтримувати відносини і зв'язки не тільки усередині своєї соціальної групи, але і з більш широким соціальним середовищем;

- обслуговування інтересів різних соціальних груп суспільства - ЗМК здійснюють інформаційну діяльність у широкому тематичному діапазоні, охоплюють інтереси широких соціальних кіл;

- здійснення впливу на масову аудиторію ЗМК як соціальні інститути мають статус офіційного джерела інформації, до якого масова аудиторія має довіру. Зміст масової комунікації дуже впливає на аудиторію в найрізноманітніших формах. Це може бути інформування, 
переконання, навіювання тощо. Вплив інформації залежить від того, наскільки вона відповідає соціальним запитам аудиторії і наскільки регулярна;

- здатність індивідуалізувати інформацію для масової аудиторії, відкритість та діалогічність - ЗМК здійснюють зв'язок як масового характеру, так і міжособистісного. Телебачення, радіо мають можливість реалізувати опосередковану міжособистісну комунікацію, включаючи іiі в різні програми, популярні інтерв'ю i бесіди. Комп'ютерні відеоігри і програми призначені для індивідуального користування. Ці нововведення видозмінюють природу ЗМК і розширюють їхні функції.

Вивчення та аналіз наукової літератури із соціології, психології, педагогіки, журналістики дали змогу встановити, що засоби масової масової комунікації стали важливим чинником формування особистості, іiі світогляду та моделі поведінки. Вони здійснюють культурний, виховний, ідеологічний, політичний вплив на людей, мають значні можливості здійснювати вплив на аудиторію, формувати свідомість і навіть змінювати спосіб мислення громадян. Це зумовлено: широтою аудиторії, спрямованістю і швидкістю інформаційного впливу; силою, комунікативністю, постійністю, систематичністю та багатофакторністю впливу; єдністю освітнього, виховного та інформаційного впливу; широким арсеналом засобів та форм впливу; доступністю, динамічністю та мобільністю інформації.

У працях Є. Прохорова виділялися, зокрема, такі функції засобів масової комунікації, як: комунікативна - функція спілкування, налагодження контакту; безпосередньо-організаторська, в якій найбільш наочно проявляється роль журналістики як «четвертої влади» у суспільстві; ідеологічна (соціально-орієнтуюча), яка пов'язана із прагненням здійснити вплив на світоглядні основи та ціннісні орієнтації аудиторії, на самосвідомість людей, їхні ідеали і прагнення, включаючи мотивацію поведінкових актів; культурно-освітня, яка полягає у пропаганді й поширенні в житті суспільства високих культурних цінностей, вихованні людей на зразках загальносвітової культури; рекламнодовідкова, пов'язана із задоволенням утилітарних запитів, інтересів та захоплень різних верств аудиторії (сад, город, туризм, колекціонування, шахи тощо); рекреативна (розваги, зняття напруги, отримання задоволення).

У дослідженнях соціологів (Д. Берета, C. Моріарті, Е. Роджерса та інших) обгрунтовувалися загальні функції, що реалізовуються засобами масової комунікації у суспільному житті. Вони зазначали, що засоби масової комунікації сприяють пізнанню навколишнього середовища, виробленню ціннісних орієнтирів, соціалізації особистості, освіті та вихованню, поширенню культури, участі в управлінні суспільними процесами тощо. У роботах вітчизняних соціологів ця проблема також досліджувалася, зокрема в межах теорії журналістики. Так, на думку $Є$. Прохорова, ЗМК беруть участь у формуванні масової свідомості у всіх іiі формах (Прохоров, 2007).

На думку більшості фахівців (Н. Лумана, Т. Парсона, К. Майера, Г. Лассан, Е. Пратконіса), провідними функціями ЗМК є комунікативна та інформаційна. Через ЗМК відбувається ознайомлення аудиторії 3 інформацією про навколишню дійсність. Публікації високоавторитетних засобів масової комунікації здатні робити значний вплив на суспільні погляди і коригувати їх.

Висновки i перспективи подальших досліджень. Таким чином, ми можемо зробити висновки, що засоби масової комунікації стали важливим чинником формування особистості, iï світогляду та моделі поведінки, вони мають значні можливості здійснювати культурний, виховний, ідеологічний, політичний вплив на людей, формувати свідомість і навіть змінювати спосіб мислення громадян.

ЗМК як соціально-педагогічному інституту притаманні такі риси, як: соціальна природа, форми та технології впливу на свідомість людей. Зміст діяльності цього інституту становить інформування широких верств населення про моральні норми та правила поведінки, науково-педагогічні здобутки; розвиток духовної, естетичної, фізичної, трудової, правової культури аудиторії; поширення передового педагогічного досвіду тощо.

Розповсюдження передового педагогічного досвіду засобами масової комунікації реалізується в інформаційному, комунікаційному, навчальному та експертному напрямах. 


\section{ЛІТЕРАТУРА:}

1. Баришполець О. Чинники впливу засобів масової інформації на аудиторію. Соціальна психологія. 2014. № 4(6). С. 61-70.

2. Городяненко В.Г. Соціологія: підручник. Київ : Видавничий центр «Академія», 2003. 559 с.

3. Зернецька О.В. Глобальний розвиток систем масової комунікації і міжнародні відносини. Київ : Освіта, 2019. $351 \mathrm{c}$.

4. Квіт С. Масові комунікації: підручник. Київ : Вид. Дім «Києво-Могилянська академія», 2008. 206 с.

5. Макеєв С.О. Соціологія : Навч.посібник. Київ : Знання, 2003. 454 с.

6. Онуфріснко Г. Термін комунікація в поняттєвому вимірі й лінгвістичному контексті. Вісник Нац.. ун-ту «Львівська політехніка». Серія «Проблеми украӥнської термінологї̈». 2015. № 67. с. 154-160.

7. Почепцов Г.Г. Теорія комунікації. Київ: Видавничий центр «Київський університет», 1999. 308 с.

8. Прохоров Е.П. Журналист и массовое сознание. Москва : Изд-во «РИП-холдинг», 2007.94 с.

9. Фомичева И.Д. Социология СМИ: учебное пособие. Москва, 2007. 333 с.

10. Юрій М.Ф. Людина і світ: підручник. Київ : Дакор,2006. 460 с.

\section{REFERENCES:}

1. Baryshpolets O. (2014.) Chinniki vplivu zasobiv masovoï informaciï na auditoriyu. [Factors influencing the media on the audience.] Social Psychology. № 4 (6). C. 61-70.

2. Gorodyanenko V.G. (2003.) Sociologiya [Sociology ]: Couresbook. Kyiv : Publishing Center "Akademiy ", 559 p.

3. Zernetskaya O.V. (2019.) Global'nij rozvitok sistem masovoï komunikaciï i mizhnarodni vidnosini. [Global development of mass communication systems and international relations]. Kyiv : Osvita, $351 \mathrm{p}$.

4. Kvit S. (2008.) Masovi komunikaciï [Mass communications]: Cousebook. Kyiv : Vid. Dim «Kievo-Mogilyans'ka akademiya», $206 \mathrm{p}$.

5. Makeev S.O. (2003.) Sociologiya [Sociology]: Cousebook. Kyiv : Znannia,. 454 p.

6. Onufrienko G. (2015.) Termin komunikaciya v ponyattevomu vimiri j lingvistichnomu konteksti. [The term communication in the conceptual dimension and linguistic context.] Bulletin of the National Lviv Polytechnic University. Seriya «Problemi ukraïns'koï terminologï»». № 67. p. 154-160.

7. Pocheptsov G.G. (1999.) Teoriya komunikaciï. [Communication theory.] Kyiv : Publishing Center «Kiïvs'kij universitet», $308 \mathrm{p}$.

8. Prokhorov E.P. (2007) Zhurnalist i massovoe soznanie. [Journalist and mass consciousness.] Moscow : Publishing House "RIP-Holding", 94 p.

9. Fomicheva I.D. (2007.) Sociologiya SMI. [Sociology of the media: Cousebook.] Moscow, 333 p.

10. Yuri M.F. (2006.) Lyudina i svit. Man and the world: Cousebook. Kyiv: Dakor, 2006. 460 c. 